\title{
Analisis Pemodelan Arus Geostropik di Perairan Indonesia menggunakan Data Satelit Altimetri
}

Geostrophic Current Modelling Analysis in Indonesian Seas using Altimetry Satellite Data

\author{
Desi Suci Richasari*1, Eko Yuli Handoko*2 \\ ${ }^{1,2}$ Departemen Teknik Geomatika, FTSLK-ITS, Kampus ITS Sukolilo, Surabaya, 60111, Indonesia \\ *Korespondensi penulis: desi.suci16@mhs.geodesy.its.ac.id ${ }^{1}$, ekoyh@geodesy.its.ac.id ${ }^{2}$
}

Diterima: 14082020; Diperbaiki: 24082020; Disetujui: 02092020; Dipublikasi: 21012021

\begin{abstract}
Abstrak: Studi ini bertujuan untuk menentukan dan menganalisis arus geostropik terhadap indeks ENSO dan indeks musim. Lokasi studi ini terletak di sekitar lautan Indonesia dengan koordinat $20^{\circ} \mathrm{N}-20^{\circ} \mathrm{S}$ dan $90^{\circ} \mathrm{E}-150^{\circ} \mathrm{E}$. Altimetri data satelit Jason Series sangat berguna sebagai penyedia data laut global, termasuk informasi tentang arus laut permukaan dan dinamika permukaan laut. Untuk menentukan arus geostropik, kami menggunakan algoritma geostropik dan metode analisis menggunakan koefisien korelasi hasil antara parameter penelitian dengan nilai indeks. Analisis temporal dan spasial menggunakan Matlab dan ArcMap untuk memvisualisasikan parameter yang diperoleh. Hasil penelitian ini menunjukkan bahwa korelasi antara anomali permukaan laut (SLA) dengan Multivariate ENSO Index (MEI) menunjukkan nilai negatif, menunjukkan bahwa SLA memiliki kondisi yang berlawanan dengan fenomena ENSO. El Nino yang kuat terjadi pada tahun 2015 dan La Nina terjadi pada tahun 2010. Perbedaan SLA tidak mempengaruhi arah arus geostropik tetapi mempengaruhi kecepatannya. Korelasi arus geotropik komponen zonal dengan AUSMI adalah 0,720 dan WNPMI adalah 0,446. Ini berarti bahwa arus geostropik memiliki arah yang sama dengan aliran angin musim.
\end{abstract}

Copyright $\odot 2020$ Geoid. All rights reserved.

\begin{abstract}
This research aims to determine and analyze the geostrophic current towards the monsoon index and the ENSO index. The location of this research is around Indonesian seas with coordinates of $20^{\circ} \mathrm{N}-20^{\circ} \mathrm{S}$ and $90^{\circ} \mathrm{E}-$ $150^{\circ}$ E. Jason Series altimetry satellite data is very useful as a provider of data on global marine affairs, including information about sea surface and sea level currents. To determine the geostrophic current, we used the geostrophic algorithm and the method of analysis used the coefficient correlation of the results between the research parameters with the index. Temporal and spatial analysis using Matlab and ArcMap to visualize the parameters which is obtained. The results of this study indicate that the corelation between Sea Level Anomalies (SLA) to the Multivariate ENSO Index (MEI) shows the negative value. It means that SLA at Indonesian seas have opposite condition. The strong El Nino occurred in 2015 and La Nina occurred in 2010. The SLA difference does not affect the direction of geostrophic current but affect its velocity. The correlation of zonal component geotrophic current to AUSMI 0,720 and WNPMI is 0,446. That means the geostrophic current have the same direction with the wind flow respectively at the moonson season.
\end{abstract}

Kata kunci : altimetri; arus geostropik; Indeks Monsun; Multivariate ENSO Index; sea surface height.

\section{Pendahuluan}

Indonesia mempunyai luas perairan sebesar $\pm 5,9 \mathrm{~km}^{2}$. Diapit oleh Samudera Pasifik dan Samudera Hindia (Lasabuda, 2013). Adanya perbedaan massa air pada kedua samudera tersebut menyebabkan adanya aliran massa air dari Samudera Pasifik menuju Samudera Hindia yang dikenal dengan Indonesian Trough Flow (ITF). ITF memberikan dampak yang signifikan pada suhu permukaan laut, freshwater budgets dan sistem iklim (Gordon, 2005). Arus (aliran massa air) memainkan peranan penting dalam memodifikasi cuaca dan iklim global (Keith A. Sverdrup, 2002). Jenis arus laut yang berdampak pada iklim global adalah arus geostropik. 
Arus geostropik adalah arus yang terjadi karena adanya keseimbangan geostropik. Rujukan (Flavien Mercier, 2018) menyatakan bahwa keseimbangan geostropik terjadi apabila gradien tekanan horizontal pada massa air yang bergerak diimbangi oleh gaya coriolis yang timbul akibat rotasi bumi. Arus ini terkait dengan kemiringan (slope) permukaan laut lebih tinggi dengan yang lebih rendah yang dibentuk oleh transpor Ekman (Ivonne M. Radjawane, 2013). Transpor Ekman adalah transpor massa air yang arahnya tegak lurus ke kanan arah angin di belahan bumi utara dan ke arah kiri di belahan bumi selatan dikarenakan adanya perubahan kecepatan arus terhadap kedalaman (Leif N.Thomas, 2017). Karena itu, pergerakan arus ini terkait dengan ketinggian permukaan laut.

Ketinggian permukaan laut atau Sea Surface Height (SSH) merupakan tinggi muka laut yang tereferensi pada bidang ellipsoid. Dengan perkembangan teknologi satelit altimetri menjadi alternatif dalam memenuhi kebutuhan data-data oseanografi berupa ketinggian permukaan laut dan dinamika laut lainnya baik yang bersifat regional maupun global. Data SSH dapat menghasilkan pola arus geostropik permukaan.

Penelitian tentang variabilitas arus geostropik telah banyak dilakukan, namun belum untuk perairan Indonesia. Penelitian variasi permukaan laut dan geostropik permukaan pernah dilakukan di Laut Arafura dan Selat Sunda, dimana ditemukan bahwa variasi musiman pada ketinggian permukaan laut Selat Sunda menyebabkan musim hujan (Parluhutan Manurung, 2011). Penelitian variasi musiman arus geostropik di perairan Arafura Timor menemukan bahwa dinamika arus geostropik permukaan di perairan Arafura -Timor terjadi akibat perubahan ketinggian permukaan laut akibat muson setiap musim (Ivonne M. Radjawane, 2013). Hasil dari dua penelitian ini menyatakan bahwa muson sangat mempengaruhi variabilitas arus geostropik. Faktor lain yang berperan dalam sirkulasi arus geostropik adalah ITF (Gordon, 2005).

Karena lokasi perairan Indonesia strategis, maka dipengaruhi oleh muson yang berhembus secara berkala sepanjang tahun, perlu dilakukan penelitian tentang dinamika permukaan laut dan arus geostropik untuk memahami distribusi dinamika anomali tinggi permukaan laut dan pola arus secara spasial dan temporal. Analisis perubahan muka air laut dilakukan dengan mempertimbangkan komponen zonal (u) dan meridional (v) yang diwakilkan dalam periode waktu bulanan. Pembagian ini menyesuaikan tipe angin muson yang bertiup di Indonesia. Kemudian dikorelasikan dengan MEI dan Indeks Munson.

\section{Data dan Metode}

Lokasi pada penelitian ini di sekitar Laut Indonesia yang dibatasi dengan koordinat $20^{\circ} \mathrm{N}-20^{\circ} \mathrm{S}$ dan $90^{\circ}$ E-150 ${ }^{\circ}$ E. Lokasi penelitian dapat dilihat pada Gambar 1.

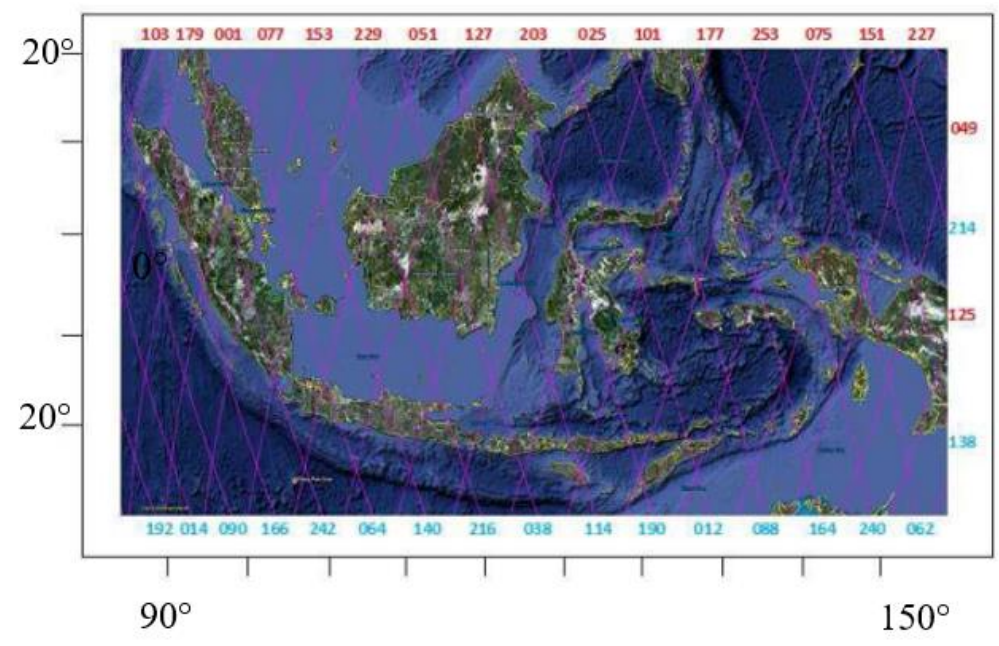

Gambar 1. Lokasi Studi Penelitian (Google Earth, 2020)

Data yang digunakan meliputi arus geostropik bulanan dan ketinggian permukaan laut sepanjang periode 10 tahun dari Januari 2009 hingga Desember 2018. Arus geostropik dan ketinggian permukaan laut yang 
digunakan berasal dari data altimetri Jason-2 dan Jason-3. Data tersebut telah dikoreksi, koreksi geofisika antara lain dry trophosperic, wet troposperic, ionosfer, tides, sea state bias, dynamic atmospheric correction, dan reference frame offset. Formulasi sederhana untuk menghitung SSH adalah sebagai berikut (Remko Scharroo, 2011):

SSH $=H-\widehat{R}-$ Geophysics Correction

Di mana $\mathrm{H}$ adalah ketinggian satelit di atas ellipsoid (altitude), $(\widehat{R})$ adalah range.

SSH telah didapatkan dan dilanjutkan dengan menghitung SLA . SLA digunakan sebagai parameter yang akan dikorelasikan dengan indeks ENSO. Ada beberapa indeks untuk memantau fenomena ENSO. Multivariate ENSO Index (MEI) adalah indeks yang paling umum digunakan untuk mendefinisikan peristiwa El Nino dan La Nina di mana MEI v.2 biasanya menggunakan rata-rata bi-mothly, dan EL Nino atau La Nina didefinisikan ketika MEI v. 2 SLA melebihi +/- 0,5. Ketika lebih besar dari 0,5 maka dinyatakan sebagai periode El Nino, ketika lebih rendah dari $-0,5$ kemudian dinyatakan sebagai periode La Nina. Dalam penelitian ini, kami menggunakan data dua bulanan MEI v.2 dari NOAA untuk menentukan episode El Nino dan La Nina, di mana SLA diubah dalam bentuk bi-monthly menyesuaikan dengan MEI v.2 selama periode 2008-2018.

Data arus geostropik di permukaan laut terdiri dari dua komponen seperti u dan v. Kecepatan arus geostropik yang diperoleh dari perhitungan menggunakan rumus di bawah ini (Stewart, 2008):

$$
u=-\frac{g}{f} \frac{\partial \zeta}{\partial y} \quad v=\frac{g}{f} \frac{\partial \zeta}{\partial x}
$$

Di mana u adalah kecepatan arus geostrofik permukaan zonal $(\mathrm{m} / \mathrm{s})$, v adalah kecepatan arus geostrofik permukaan meridional $(\mathrm{m} / \mathrm{s}), \zeta$ topografi dinamis absolut $(\mathrm{m})$, g adalah gravitasi $\left(\mathrm{m} / \mathrm{s}^{2}\right)$, dan $\mathrm{f}$ adalah parameter koriolis . Kemudian hasilnya divalidasi oleh komponen arus geostropik dari Copernicus Marine Service (CMEMS). Selanjutnya, kami menghitung resultan dari kecepatan arus geostropik untuk dibandingkan dengan kecepatan angin yang disediakan oleh ECMWF.

Salah satu analisis yang digunakan pada penelitian ini dengan cara mengitung korelasi antara arus geostrofik permukaan zonal dengan nilai indeks monsun khususnya Indeks Monsun Australia (AUSMI) dan Indeks Monsun Pasifik Utara Barat (WNPMI). Selain itu, analisis korelasi juga dilakukan perbedaan SSH dan SLA antara Samudra Pasifik barat dan Samudra Hindia timur dengan terjadinya ENSO. Persamaan korelasi yang digunakan adalah korelasi Pearson yang dirumuskan sebagai berikut:

$$
\begin{gathered}
\mathrm{Q}_{\mathrm{xy}}=\frac{\sigma_{\mathrm{xy}}}{\sigma_{\mathrm{x}} \cdot \sigma_{\mathrm{y}}} \\
\sigma_{\mathrm{xy}}=\frac{\Sigma\left(\mathrm{X}-\mu_{x}\right)\left(Y-\mu_{y}\right)}{\mathrm{n}}
\end{gathered}
$$

Di mana $\varrho_{x y}$ adalah korelasi pearson, $\sigma_{x y}$ adalah kovarians xy, $\sigma_{x}$ adalah standar deviasi x, $\sigma_{y}$ adalah standar deviasi $\mathrm{y}, \mu_{x}$ rata-rata $\mathrm{x}, \mu_{y}$ adalah rata-rata $\mathrm{y}, \mathrm{n}$ adalah jumlah sampel, $\mathrm{X}$ adalah variabel independen, $\mathrm{Y}$ adalah variabel dependen. Tingkat hubungan antara variabel-variabel dalam analisis korelasi didasarkan pada nilainilai pada Tabel 1. di bawah ini.

Tabel 1. Interpretasi Koefisien Korelasi (Evans, 1996)

\begin{tabular}{ll}
\hline \multicolumn{1}{c}{ Interval } & \multicolumn{1}{c}{ Tingkat Hubungan } \\
\hline $\mathbf{0 , 8 0} \leq \boldsymbol{\varrho}_{x y} \leq \mathbf{1 , 0 0}$ & Sangat Kuat \\
$\mathbf{0 , 6 0} \leq \boldsymbol{\varrho}_{\boldsymbol{x} y}<\mathbf{0 , 8 0}$ & Kuat \\
$\mathbf{0 , 4 0} \leq \boldsymbol{\varrho}_{\boldsymbol{x} y}<\mathbf{0 , 6 0}$ & Cukup Kuat \\
\hline
\end{tabular}




\begin{aligned} & \hline $\mathbf{0 , 2 0} \leq \varrho_{x y}<\mathbf{0 , 4 0}$ Lemah \\ &$\varrho_{x y}<\mathbf{0 , 2 0}$ Sangat Lemah \\ & \hline\end{aligned}

\section{Hasil dan Pembahasan}

\section{Validasi Data Arus}

Validasi data arus hitungan dengan arus model yang telah di unduh sebelumnya. Antara data model dengan data hitung dimana terdapat perenggangan data di tahun 2015-pertengahan 2016, selebihnya pola menunjukkan kemiripan. Dengan RMSE komponen $u$ sebesar 0,217 dan komponen $v$ sebesar 0,180. Nilai korelasi pada titik ini masing-masing untuk komponen $u$ sebesar 0,715 dan untuk komponen $v$ sebesar 0,331. Nilai korelasi yang mendekati satu dan RMS-Error yang kecil menunjukkan data model dan data hitungan memiliki korelasi yang tinggi dan perbedaan nilai data yang rendah.

a)

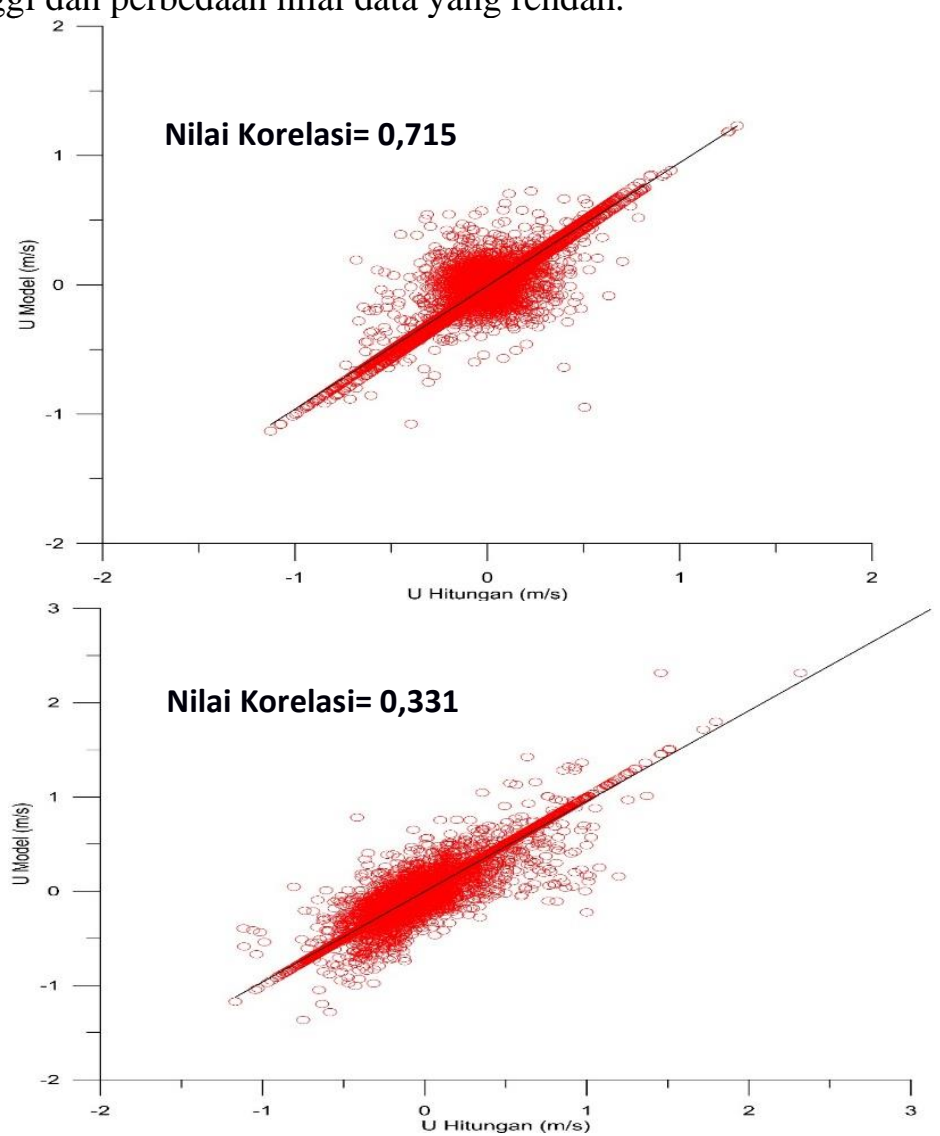

Gambar 2. a) Scatter plot $u$ model dengan $u$ hitungan b) Scatter plot $v$ model dengan $v$ hitungan

\section{Pemodelan Pola Arus Geostropik}

Pemodelan arus geostropik dilakukan dengan kurun waktu pengamatan 2009-2018 yang telah dikelompokkan perbulan berdasarkan pola musiman. Pola musiman di daerah tropis terbagi menjadi dua yaitu Musim Barat (Desember, Januari, Februari) dan Musim Timur (Juni, Juli, Agustus). Diantaranya terdapat Musim Peralihan I (Maret, April, Mei) dan Musim Pelahian II (September, Oktober, November).

\section{a. Musim Barat}

Gambar 7. menampilkan pola angin dan pola arus secara spasial di perairan Indonesia pada periode musim barat. Secara umum pada periode ini, angin dari barat laut menuju ke timur untuk lintang $5^{\circ} \mathrm{LU}-5^{\circ} \mathrm{LS}$ mempunyai kecepatan rata- rata sebesar 4,50 m/s. Dengan kecepatan angin dominan pada bulan Januari. Pola 
yang hampir sama di tunjukkan oleh arus, dimana pada daerah Samudera Pasifik angin berasal dari timur menuju ke barat, masuk ke Perairan Indonesia melalui Selat Makasar dan Laut Maluku kemudian kearah selatan dan berbelok ke barat menuju Samudera Hindia. Alur arus ini dikenal dengan Arus Lintas Indonesia (ARLINDO). Kecepatan rata-rata arus pada musim barat sebesar $0,217 \mathrm{~m} / \mathrm{s}$ dan kecepatan rata-rata arus terbesar pada bulan Januari. Hal ini menjadikan angin dan arus di bulan Januari menjadi puncak pada Musim Barat dengan besaran yang paling kuat.
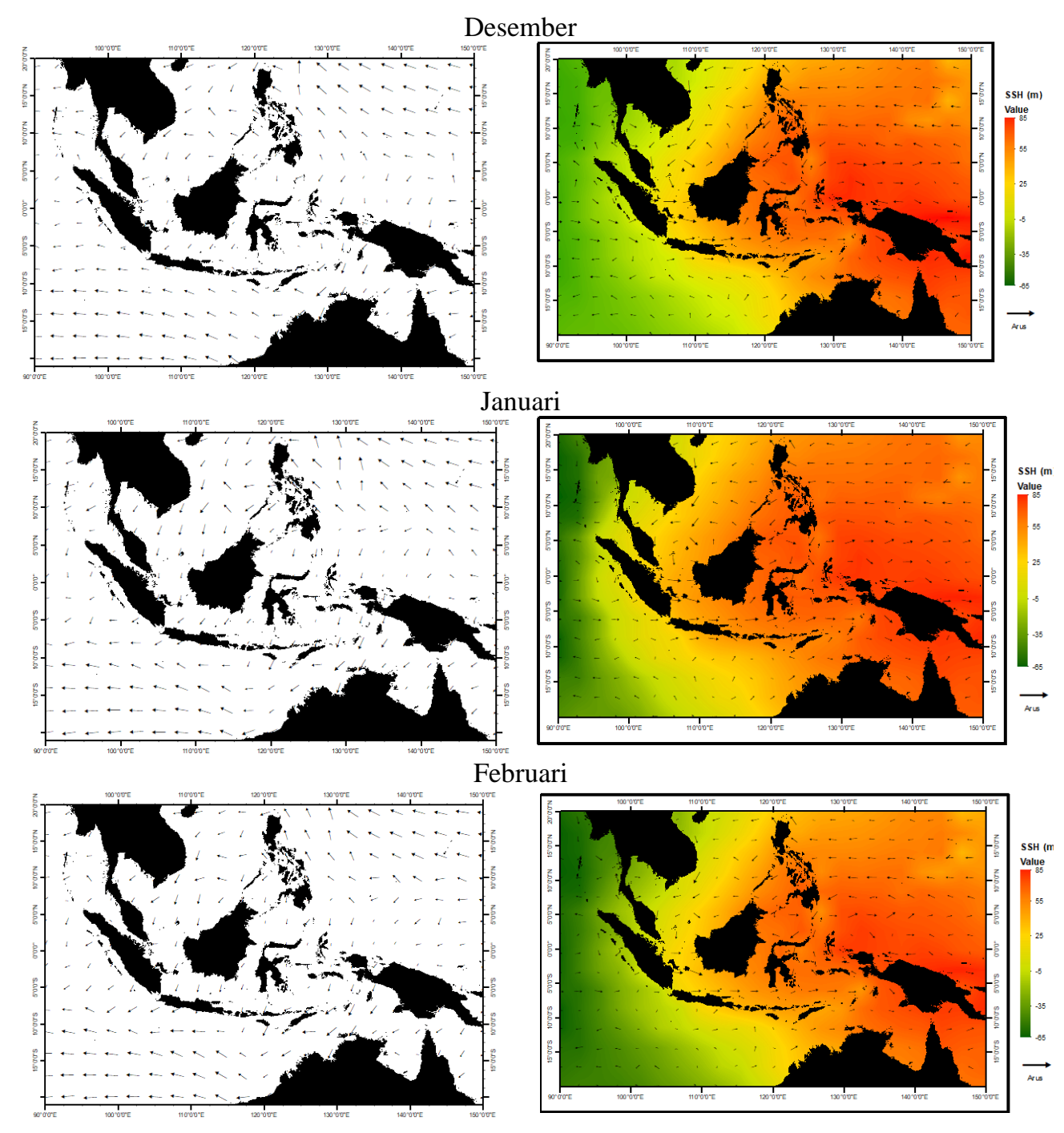

Gambar 3. Distribusi spasial angin (kiri) dan overlapping arus gestropik permukaan dengan SSH selama Musim Barat.

Arus laut mengalir dari SSH yang tinggi menuju SSH yang rendah ( Yin S. Soon, 2000). SSH tinggi ditandai dengan warna oranye dan SSH rendah ditandai dengan warna hijau dengan range nilai $85 \mathrm{~m}$ s/d $-65 \mathrm{~m}$. Berdasarkan Gambar 7 Laut Andaman dan Samudera Hindia mempunyai SSH yang tergolong rendah. Arus dari Laut Cina Selatan dengan SSH yang lebih tinggi menuju Indonesia melalui Selat Karimata menuju utara Laut Jawa yang SSH nya lebih rendah. Begitu pula yang terjadi pada Samudera Pasifik dengan SSH tinggi mengalir melalui Selat Makasar dan Laut Maluku menuju Samudera Hindia dengan SSH yang rendah. Namun arus pada lintang $0^{\circ}-5^{\circ} \mathrm{LS}$ mengarah ke SSH yang lebih tinggi, dari Laut Andaman dan Samudera Hindia menuju Selat Sunda dan Laut Jawa . Fenomena itu dapat terjadi karena musim ini angin bertiup dari barat ke timur dengan kecepatan yang kuat dan membawa massa air yang relatif terhadap arah arus (Sri Suryo Sukoraharjo, 2016). 


\section{b. Musim Perlaihan I}

Pola arus dan angin saat Musim Peralihan I ditampilkan pada Gambar 8. peralihan dari Musim Barat ke Musim Timur menyebabkan terjadinya pelemahan baik pada arus maupun angin. Kecepatan angin rata-rata periode ini sebesar 3,952 m/s dan 0,17 m/s untuk kecepatan arusnya. Arus bulan Maret dan April pada lintang $5^{\circ} \mathrm{LU}-$ $10^{\circ} \mathrm{LS}$ arah arus dominan menuju timur. Berbeda dengan arah angin yang dominan menuju ke barat.
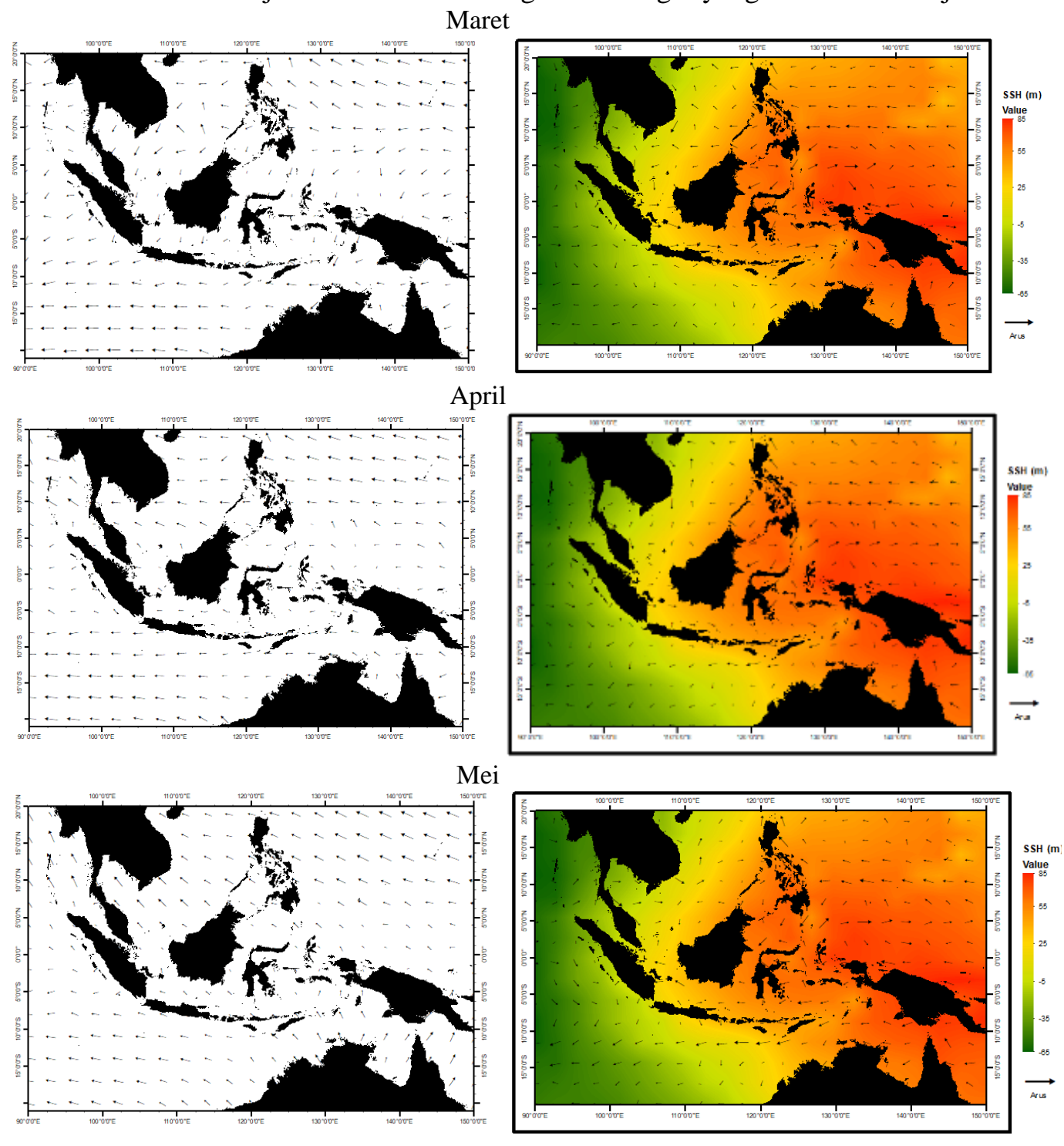

Gambar 4. Distribusi spasial angin (kiri) dan overlapping arus gestropik permukaan dengan SSH selama Musim Peralihan I

Pada bulan Mei mulai terjadi perubahan arah pada angin dan arus. Angin dari tenggara menuju barat laut, pada equator di belokkan ke kiri. Arus dari tenggara melalui Laut Timor terbelah dua ke perairan Indonesia dan Samudera Hindia. Arus mengalir ke perairan Indonesia melalui Laut Flores, Laut Jawa dan kearah utara menuju Selat Karimata.

\section{c. Musim Timur}

Pola angin dan arus Musim Timur ditampilkan pada Gambar 9. Menunjukkan bahwa pola angin yang berasal dari timur dan tenggara serta arus yang secara umum menuju kearah barat dan barat laut. Angin pada musim ini mempunyai nilai yang tinggi dalam siklus tahunannya. Kecepatan angin rata-rata sebesar 4,913 m/s. Sama 
halnya dengan angin, arus pada musim ini mempunyai arah dan besaran yang hampir sama setiap bulan pada musim ini. Kecepatan arus rata-rata sebesar $0,189 \mathrm{~m} / \mathrm{s}$. Arus yang mempunyai besaran dominan berada di utara perairan Papua, Laut Banda, Laut Flores dan Laut Timor. Arus ini dikenal dengan Arus PantaiPapua yaitu arus yang menyusuri pantai utara Papua dan berasal dari selatan Samudera Pasifik. Arus geostropik dari Laut Banda mengalir ke Laut Flores, tetapi ada persimpangan ITF. Aliran arus ini mengarah ke Laut Flores dan yang lainnya mengarah ke Laut Timor. Hal itu terjadi karena perbedaan SSH yang signifikan antara Laut Timor dan laut sekitarnya tahu bahwa ada Dangkalan Sahul dengan kedalaman dangkal dan laut lainnya memiliki kedalaman yang dalam, sehingga arah arus dapat berubah (Ivonne M. Radjawane, 2013).
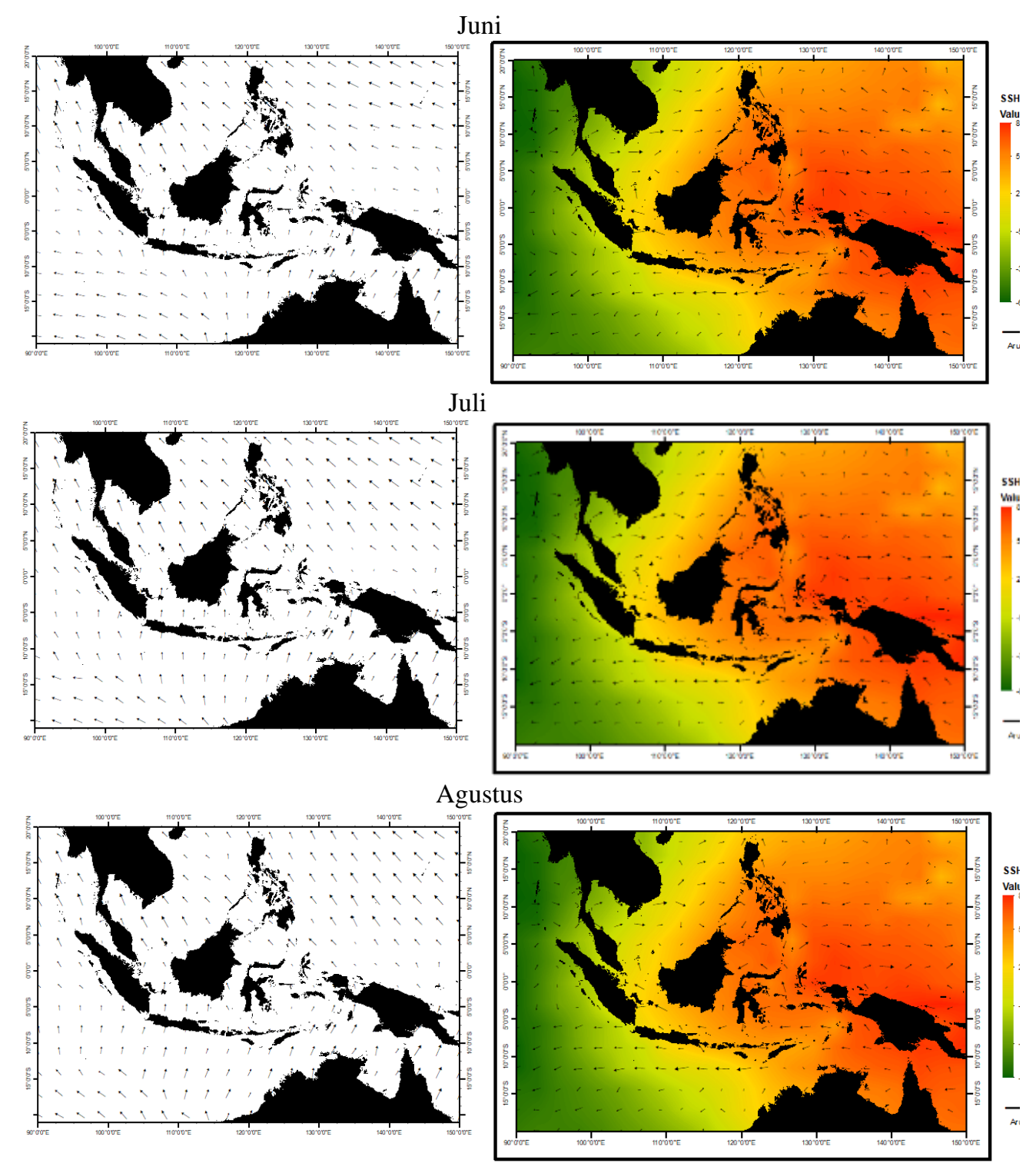

Gambar 5. Distribusi spasial angin (kiri) dan overlapping arus geostropik permukaan dengan SSH selama Musim Timur.

\section{d. Musim Peralihan II}

Gambar 10 menunjukkan pola arus dan angin pada Musim Peralihan II, musim ini merupakan peralihan dari Musim Timur menuju Musim Barat yang diwakili oleh bulan September, Oktober dan November. Arah arus yang terjadi pada musim ini masih dominan ke arah barat dan barat laut seperti pada musim timur yang terjadi 
pada lintang $10^{\circ} \mathrm{LU}-20^{\circ} \mathrm{LU}$ dan $10^{\circ} \mathrm{LS}-20^{\circ} \mathrm{LS}$. Secara perlahan besaran kecepatan arus melemah untuk bulan September ke Oktober dan mulai naik pada bulan November.

September
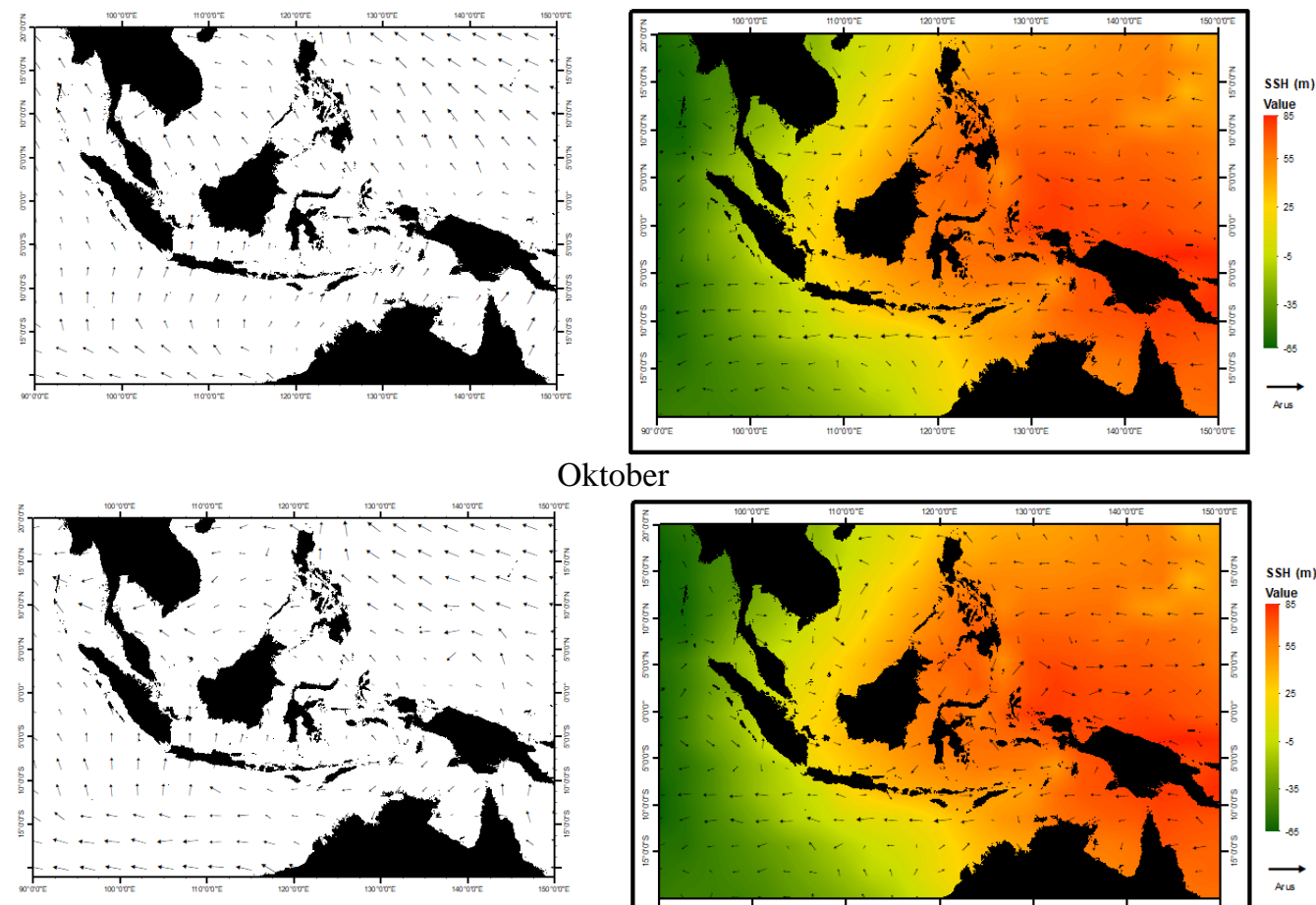

Oktober

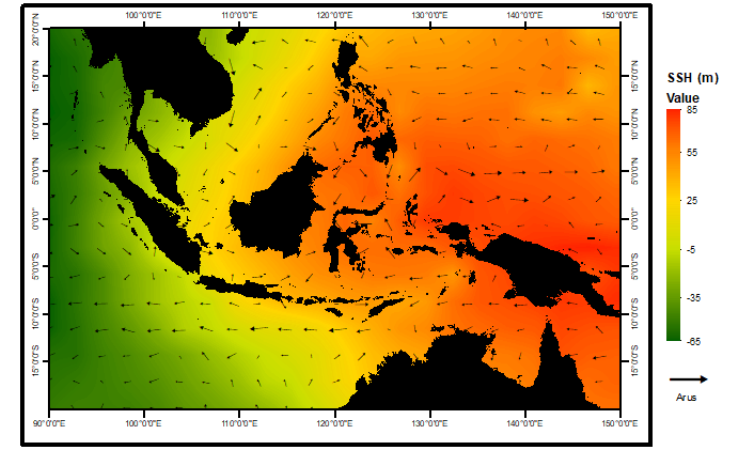

November
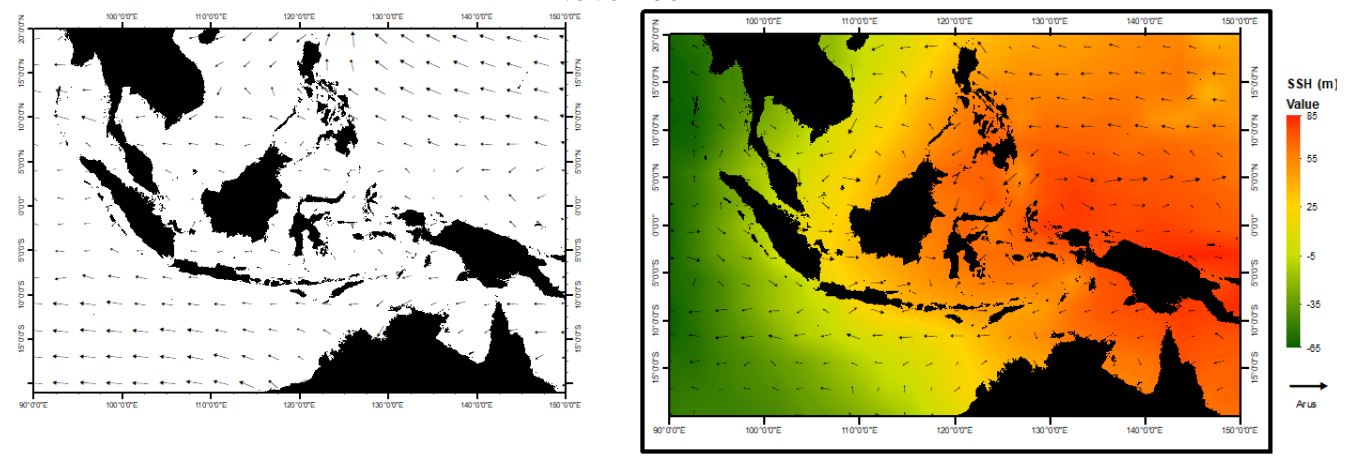

Gambar 6.Distribusi spasial angin (kiri) dan overlapping arus gestropik permukaan dengan SSH selama Musim Peralihan II.

\section{Korelasi dengan Indeks}

\section{a. SLA dengan MEI}

Korelasi SLA dengan MEI adalah -0,66 maka tingkat hubungan 2 variabel tersebut kuat, namun berbanding terbalik. El Nino terjadi ketika nilai MEI positif dan La Nina terjadi ketika nilai MEI negatif. Berdasarkan Gambar 11. terjadi peristiwa El Nino paling kuat pada tahun 2015 dan La Nina paling kuat terjadi tahun 2010. Ketika terjadi El Nino kuat kondisi SLA di Samudera Pasifik lebih rendah dari pada Samudera Hindia hal ini dikarenakan curah hujan terjadi dengan intensitas kecil pada waktu El Nino sehingga dimungkinkan mempengaruhi kenaikan permukaan air laut di Samudera Pasifik khususnya. Saat La Nina SLA di Samudera Pasifik menunjukkan warna yang cenderung orange yang menunjukkan bahwa SLA mempunyai nilai yang lebih tinggi dibandingkan dengan Samudera Hindia.(Eko Yuli Handoko, 2018). 


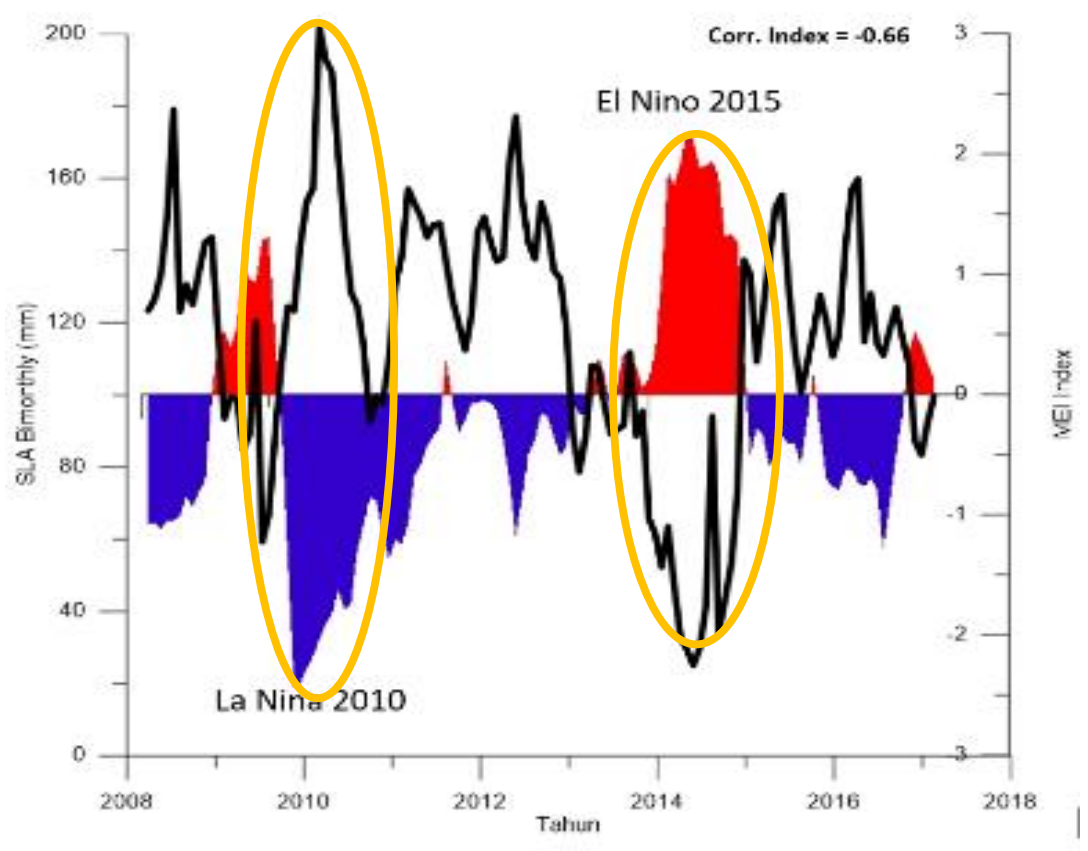

Gambar 7. Relasi antara SLA dan MEI

\section{b. Arus Geostropik dengan MEI}

Korelasi antara kecepatan arus geostropik rata-rata dengan MEI adalah 0,24. Hal ini menunjukkan hubungan antara kedua variabel lemah dan berjalan searah. Rata-rata kecepatan arus geostropik di Perairan Indonesia pada saat El Nino lebih tinggi daripada saat La Nina, hal ini dikasrenakan SLA pada saat La NiNA Lebih tinggi, sehingga kecepatan arus geostropik lebih tinggi pula. Perbedaan kecepatan arus ketika El Nino (2015) dan La Nina (2010) terjadi adalah $0,54 \mathrm{~m} / \mathrm{s}$.

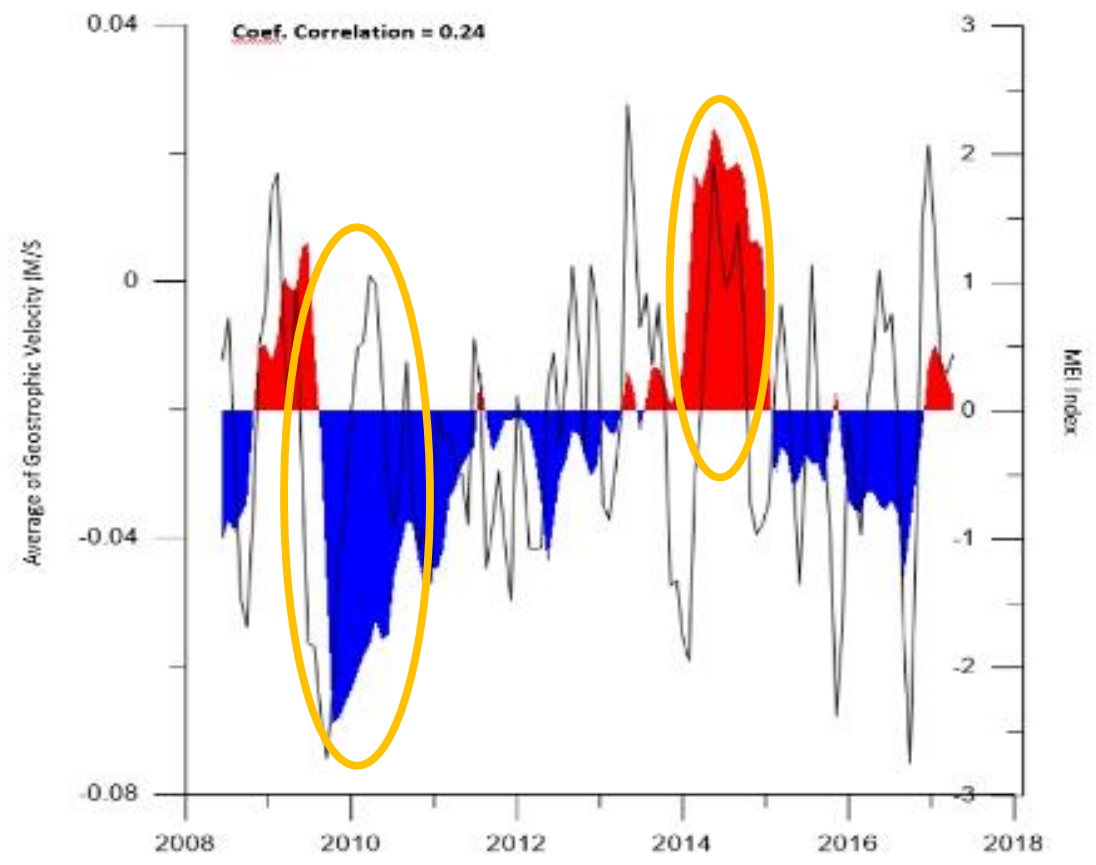

Gambar 8. Kecepatan arus geostropik selama fenomena ENSO (2009-2018) 


\section{c. Arus Zonal dengan AUSMI}

Tabel 2 adalah hasil perbandingan arus zonal tahun 2009 hingga 2015 serta nilai indeks AUSMI.

Tabel 2. Arus Zonal dan Indeks AUSMI (2009-2015)

\begin{tabular}{rlrr}
\hline Tahun & Bulan & Arus Zonal $(u)(\mathrm{m} / \mathrm{s})$ & AUSMI \\
\hline 2009 & Desember & $-0,027$ & $-0,161$ \\
2009 & Januari & $-0,006$ & 0,434 \\
2009 & Februari & $-0,035$ & 0,427 \\
2010 & Desember & $-0,003$ & 1,092 \\
2010 & Januari & $-0,007$ & 0,579 \\
2010 & Februari & $-0,053$ & $-0,645$ \\
2011 & Desember & $-0,012$ & 0,122 \\
2011 & Januari & $-0,002$ & 1,491 \\
2011 & Februari & 0,001 & 0,911 \\
2012 & Desember & $-0,061$ & $-1,200$ \\
2012 & Januari & $-0,002$ & 0,127 \\
2012 & Februari & $-0,046$ & $-1,563$ \\
2013 & Desember & $-0,037$ & $-0,492$ \\
2013 & Januari & $-0,015$ & 0,758 \\
2013 & Februari & $-0,042$ & $-0,424$ \\
2014 & Desember & $-0,008$ & $-0,244$ \\
2014 & Januari & $-0,007$ & 0,769 \\
2014 & Februari & $-0,001$ & 0,388 \\
2015 & Desember & $-0,005$ & 0,895 \\
2015 & Januari & $-0,046$ & 1,041 \\
2015 & Februari & $-0,049$ & $-1,277$ \\
\hline
\end{tabular}

Hasil pengolahan arus zonal terhadap indeks AUSMI menghasilkan koefisien korelasi sebesar 0,720 yang tergolong dalam klasifikasi yang sangat kuat. Yang artinya arus zonal menurut AUSMI dipengaruhi oleh angin muson. Arus bergerak ke arah yang relatif sama dengan arah angin muson. Kecepatan arus zonal pada musim hujan berkisar antara 0,061- 0,001 $\mathrm{m} / \mathrm{s}$ dengan kecepatan maksimum terjadi pada bulan Desember tahun 2012 sebesar $0,061 \mathrm{~m} / \mathrm{s}$ dan kecepatan minimum terjadi pada bulan Februari 2011 dan 2014 sebesar $0,001 \mathrm{~m} / \mathrm{s}$.

La Nina paling kuat terjadi pada tahun 2010 dan berdasarkan Tabel 4.4 AUSMI mempunyai nilai yang tinggi dan bernilai negatif pada bulan Februari senilai $-0,645$ artinya pada bulan ini memiliki curah hujan yang tinggi dengan kecepatan arus $0,053 \mathrm{~m} / \mathrm{s}$. Pada tahun $2015 \mathrm{El}$ Nino paling kuat terjadi, AUSMI menunjukkan bahwa pada bulan Desember dan Januari yang seharusnya terjadi hujan dengan intensitas tinggi, tetapi memiliki indeks sebesar 0,895 dan 1.041 yang artinya pada bulan ini curah hujan sangat rendah atau bisa disebut mengalami musim kemarau dengan kecepatan arus zonal yang kecil pula yaitu $0,005 \mathrm{~m} / \mathrm{s}$ dan 0,046 $\mathrm{m} / \mathrm{s}$.

\section{d. Arus Zonal dengan WNPMI}

Tabel 3 menunjukkan hasil perbandingan arus zonal tahun 2009 hingga 2015 serta nilai indeks WNPMI.

Tabel 3. Arus Zonal dan Indeks WNPMI (2009-2015)

\begin{tabular}{rlcr}
\hline Tahun & \multicolumn{1}{c}{ Bulan } & Arus Zonal $(u)$ & \multicolumn{1}{c}{ WNPMI } \\
\hline 2009 & Juni & 0,032 & 0,579 \\
2009 & Juli & 0,038 & 1,018 \\
2009 & Agustus & 0,034 & 0,068 \\
2009 & September & 0,012 & 2,075 \\
2010 & Juni & $-0,090$ & $-1,117$ \\
2010 & Juli & $-0,082$ & $-1,805$ \\
\hline
\end{tabular}




\begin{tabular}{llrr}
\hline 2010 & Agustus & $-0,053$ & $-0,395$ \\
2010 & September & $-0,076$ & $-2,113$ \\
2011 & Juni & 0,041 & 0,480 \\
2011 & Juli & 0,046 & 0,657 \\
2011 & Agustus & 0,077 & $-0,188$ \\
2011 & September & 0,059 & 1,037 \\
2012 & Juni & 0,020 & 1,410 \\
2012 & Juli & 0,066 & 0,796 \\
2012 & Agustus & 0,064 & 0,604 \\
2012 & September & 0,052 & 0,467 \\
2013 & Juni & 0,034 & $-0,029$ \\
2013 & Juli & 0,065 & $-0,201$ \\
2013 & Agustus & 0,052 & $-0,156$ \\
2013 & September & 0,033 & 1,336 \\
2014 & Juni & 0,026 & 0,194 \\
2014 & Juli & 0,005 & 1,605 \\
2014 & Agustus & 0,049 & $-1,335$ \\
2014 & September & 0,017 & $-0,546$ \\
2015 & Juni & 0,036 & $-0,892$ \\
2015 & Juli & 0,061 & 0,386 \\
2015 & Agustus & 0,007 & $-0,642$ \\
2015 & September & 0,023 & $-0,910$ \\
\hline
\end{tabular}

Hasil pengolahan arus zonal terhadap indeks WNPMI menghasilkan koefisien korelasi sebesar 0,446 yang tergolong dalam klasifikasi yang cukup kuat (moderate). Artinya Indeks WNPMI mempunyai pengaruh yang tidak terlalu besar terhadap kecepatan arus zonal. Kecepatan arus zonal pada musim kemarau berkisar antara 0,090- 0,005 m/s dengan kecepatan maksimum terjadi pada bulan Juni tahun 2010 sebesar $0,090 \mathrm{~m} / \mathrm{s}$ dan kecepatan minimum terjadi pada bulan Juli 2014 sebesar 0,0005 m/s.

Berdasarkan Tabel 3 pada tahun 2010 WNPMI menunjukkan nilai negatif pada bulan Juni, Juli, Agustus dan September, ini mengindikasikan bahwa pada bulan-bulan tersebut dipengaruhi oleh angin muson barat yang membawa banyak air atau dapat dikatakan memiliki curah hujan yag tinggi, peristiwa ini terjadi bersamaan dengan La Nina selaras dengan analisis sebelumnya. Begitu pula dengan kecepatan arus zonal pada bulan ini memiliki kecepatan yang relatif besar dengan rentang nilai 0,053 -0,096 m/s. Tahun 2015 kecepatan arus zonal lebih lemah dari tahun 2010, hal ini dapat terjadi karena dipengaruhi oleh peristiwa El Nino, WNPMI menunjukkan nilai 0,386 pada bulan Juli, yang artinya pada bulan ini dipengaruhi oleh angin muson timur yang membawa sedikit uap air sehingga curah hujan rendah.

\section{Analisis Temporal Sea Level Anomaly dan Arus Geostropik}

Power spectral density (PSD) didefinisikan sebagai daya (power) tiap selang frekuensi dengan amplitude sebagai unit sinyal yang di hitung dengan frekuensi digambarkan sebagai unit yang berulang (cyclic units). Fungsi dari analisis densitas spektral ini untuk mengetahui lama siklus dari SLA di perairan Indonesia. Hasil periodogram SLA tahunan menunjukkan pola yang konsisten. Tahun 2010, 2011, 2012, 2013, 2014, 2015, 2016, 2017 dan 2018 mempunyai pola yang sama, dengan Strong annual pattern (PSD >1) pada bulan Januari dengan energi spektral tertinggi. Annual pattern artinya pola selang 12 bulanan SLA yang berulang dengan selang waktu 2008 hingga 2018. Tahun 2008 mempunyai pola yang berbeda, pada tahun ini SLA mean memiliki energi yang lebih rendah pada bulan Januari dari tahun-tahun yang lain dengan rentang energi sebesar 0 - 0,5. Berdasarkan Gambar 13. perairan Indonesia mempunyai musim hujan dominan, pada saat SLA dengan energi spektral maksimal pada Januari. 


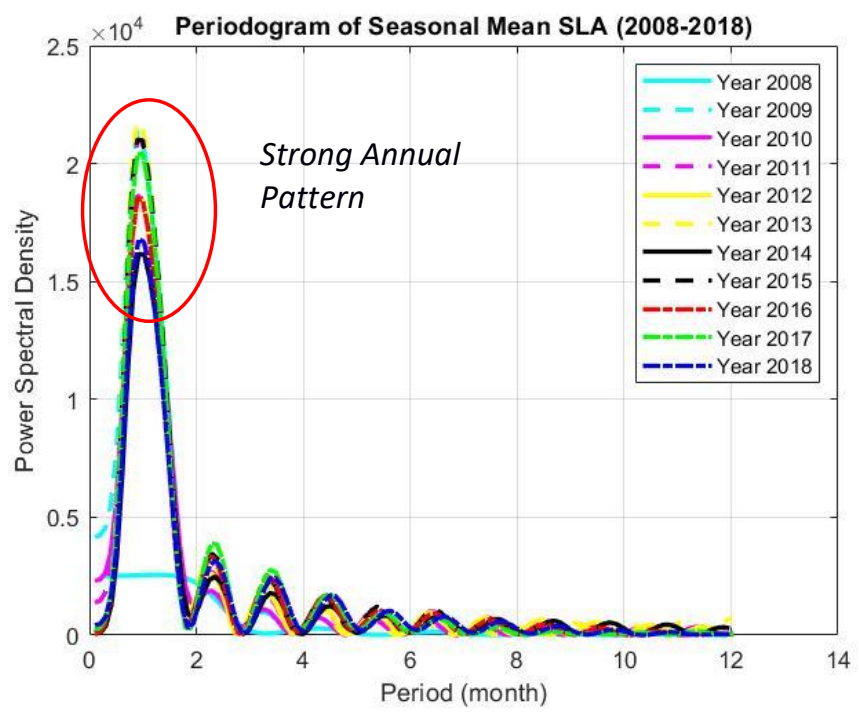

Gambar 9 Periodogram Seasonal SLA (2008-2018)

\section{Kesimpulan}

Pola arus geostropik dapat diturunkan menggunakan data altimetri satelit, memiliki kecepatan dan arah yang berbeda-beda. Dengan komponen RMSE u adalah 0,217 dan komponen v adalah 0,180 divalidasi dengan CMEMS. Arus geostropik memiliki pola di setiap musim di Musim Barat, Musim Transisi I, Musim Timur, dan Musim Transisi II. Pola yang berbeda disebabkan oleh perbedaan SSH dan perubahan angin muson untuk setiap musim.

Koefisien korelasi SLA dengan MEI -0,66, tingkat hubungan antara 2 variabel kuat, tetapi berbanding terbalik. Ini berarti bahwa fenomena ENSO mempengaruhi anomali permukaan laut di perairan Indonesia. Sementara itu, korelasi antara kecepatan arus geostropik rata-rata dan MEI adalah 0,24, yang berarti bahwa fenomena ENSO memiliki pengaruh yang lemah pada kecepatan arus geostrofik. Proses arus zonal ke indeks AUSMI menghasilkan koefisien korelasi sebesar 0,720 yang tergolong sangat korelasi yang kuat. Artinya arah angin zonal terindikasi kuat berhubungan dengan arah angin muson.

\section{Ucapan Terimakasih}

Penulis D.S.R. mengucapkan terima kasih kepada NOAA yang telah menyediakan data RADS dan Indeks ENSO, CMEMS yang telah menyediakan data arus geostropik, ECMWF yang menyediakan data angin dan pihak lain yang terkait yang tidak dapat penulis sebutkan satu persatu.

\section{Daftar Pustaka}

Eko Yuli Handoko, H. H. (2018). The ENSO's Influence on the Indonesian Sea Level Observed Using Satellite Altimetry, 1993 - 2016. IEEE Asia-Pasific Conference on Geoscience, Electronics and Remote Sensing Technology (AGERS)

Evans, J. D. (1996). Straightforward Statistics For The Behavioral Sciences. Pacific Grove : Brooks/Cole Pub.

Flavien Mercier, P. E.-H. (2018). Satellite Radar Altimetry Principle, Accuracy and Precision. In D. Stammer, \& A. Cazenave, Satellite Altimetry Over Oceans and Land Surfaces. Boca Raton, FL : CRC Press.

Gordon, A. L. (2005). Oceanography of the Indonesian Seas and Their Through Flow. Oceanography Society, Volume 18 , No 4, 14-27.

Ivonne M. Radjawane, F. (2013). Arus Geostropik Permukaan Musiman Di Perairan Arafura-Timor. Jurnal Llmu dan Teknologi Kelautan Tropis, Volume 5, 261-271.

Keith A. Sverdrup, D. A. (2002). Fundamentals of Oceanography. New York: McGraw-Hill. 
Lasabuda, R. (2013). Pembangunan Wilayah Pesisir Dan Lautan Dalam Perspektif Negara Kepulauan Republik Indonesia. Jurnal Ilmiah Paltax, 92-101.

Leif N.Thomas, J. (2017, May). Ekman Transport in Balanced Currents with Curvature. Journal of Physichal Oceanography, 47(5), 1189-1203. doi:https://doi.org/10.1175/JPO-D-16-0239.1

Munasik, H. K. (2016). Interannual Variability Of Sea Surface Height Difference Between Western Pacific Ocean and Eastern Indian Ocean and Its Effect To Geostrophic Current In Lombok Strait. IOP Conf.Ser: Earth and Evirontal Science. doi:10.1088/1755-1315/162/1/012016

Parluhutan Manurung, R. J. (2011). Sea Level Variation And Geostrophic Current Of The Sunda Strait Based On Tidal And Wind Data In Year 2008. Jurnal Ilmu dan Teknologi Kelautan Tropis, 3(2), 127-152. doi:https://doi.org/10.29244/jitkt.v3i2.7827

Remko Scharroo, O. (2011). Range and geophysical corrections in coastal regions: and implications for mean sea surface determination. In S. P. J. Benveniste (Ed.), Coastal Altimetry (pp. 103-146). Springer.

Robert H. Stewart. (2008). Introduction to Physical Oceanography.

Sri Suryo Sukoraharjo, H. A. (2016). Pola Sirkulasi Dan Variabilitas Arus Di Perairan Selat Sunda. Jurnal Kelautan Nasional, 11(3), 141-157.

Teguh Prayogo, S. (2014). Analisis Arus Geostropik Permukaan Laut Berdasarkan Data Satelit Altimetri. Seminar Nasional Penginderaan Jauh, 561-567.

Yin S. Soon, C.-R. Q. (2000, June 15). Seasonal Variability Of Sea Surface Height In The South China Sea. Journal Of Geophysical Research,, 105, 13981-13990. 